University of Nebraska - Lincoln

DigitalCommons@University of Nebraska - Lincoln

USDA Forest Service / UNL Faculty Publications U.S. Department of Agriculture: Forest Service -National Agroforestry Center

2013

Transferring site information for black walnut from native woodlands in southeastern Kansas USA to identify sites for agroforestry practices

\author{
Wayne A. Geyer \\ Kansas State University, wgeyer@ksu.edu \\ Felix Ponder Jr \\ USDA Forest Service
}

Follow this and additional works at: https://digitalcommons.unl.edu/usdafsfacpub

Geyer, Wayne A. and Ponder, Felix Jr, "Transferring site information for black walnut from native woodlands in southeastern Kansas USA to identify sites for agroforestry practices" (2013). USDA Forest Service / UNL Faculty Publications. 251.

https://digitalcommons.unl.edu/usdafsfacpub/251

This Article is brought to you for free and open access by the U.S. Department of Agriculture: Forest Service -National Agroforestry Center at DigitalCommons@University of Nebraska - Lincoln. It has been accepted for inclusion in USDA Forest Service / UNL Faculty Publications by an authorized administrator of DigitalCommons@University of Nebraska - Lincoln. 


\title{
Transferring site information for black walnut from native woodlands in southeastern Kansas USA to identify sites for agroforestry practices
}

\author{
Wayne A. Geyer - Felix Ponder Jr.
}

This article is a U.S. government work, and is not subject to copyright in the United States.

Received: 26 August 2011 / Accepted: 18 April 2012/Published online: 15 May 2012

(C) Springer Science+Business Media B.V. 2012

\begin{abstract}
Black walnut (Juglans nigra) is an important tree species for temperate agroforestry in the United States for timber, nuts, wildlife, and abrasives. Predictions of forestland productivity are needed for proper species selection in tree planting. Potential productivity can be estimated for nonforested areas and agricultural croplands by relating site quality to site and soil characteristics. Our study measured the growth potential of black walnut in natural stands. We looked at over 210 stands on unglaciated soils in southeastern Kansas with the site index at 50 years ranging from 9.1 to $26.8 \mathrm{~m}$. Numerous environmental factors were evaluated, including: site, soil chemical, and soil physical properties. These environmental factors were related to tree height at the standard age of 50 years. Simple correlation and multiple regression analyses were run with the site index using over 60 variables of soil and topographic characteristics. Understory competition had no effect on site index. Chemical characteristics had a slight effect on site index. We explained $73 \%$ of
\end{abstract}

Felix Ponder Jr., Research Soil Scientist-deceased.

W. A. Geyer $(\bowtie)$

Division of Forestry, Kansas State University, Throckmorton Hall, Manhattan, KS 66506, USA

e-mail: wgeyer@ksu.edu

F. Ponder Jr.

Northern Research Station, USDA Forest Service,

Columbia, MO 65211, USA the variation in site index with just two variables; depth to a restrictive layer (DRL) and soil type. DRL is a good predictor of walnut productivity.

Keywords Juglans nigra - Southeast Kansas · Site $\cdot$ Site index $\cdot$ Soil $\cdot$ Restrictive soil depth

\section{Introduction}

Black walnut (Juglans nigra L.) is an important tree species in temperate agroforestry for the United States (Garrett et al. 2000). It is commonly a significant tree component in farmstead woodlots, riparian areas, and alley cropping design plantings. Walnut is a highly prized hardwood, has flavorful nuts for human and wildlife consumption, and provides nut shell abrasives for the drilling industry (Ares and Brauer 2004). Highquality abandoned cropland offers an opportunity to rebuild and expand existing woodlots consisting of species with high commercial value such as black walnut. Lower quality sites provide areas for nut production or cattle protection. Forage grasses grow well under walnut having up to $50 \%$ incident radiation reaching the ground to support forage growth (Van Sambeek 1991). It is a high value tree for riparian areas with short flood duration flooding. (Kabrick et al. 200X).

The natural range of walnut extends westward into central Kansas (Brinkman 1957) and is a major component of the prairie forest fringe environment 
in eastern third of Kansas. It is found on a wide variety of ecological sites. Nearly pure stands of black walnut are common; this species occurs in small patches along river valleys, side drainages, and adjacent slopes, and is often bordered by abandoned cropland and abused pasture-land (Grey and Naughton 1971).

Researchers have been identifying and considering problems involved in growing black walnut for a number of years. This work has lead to a better understanding of black walnut culture and some specific needs to increase regeneration success of the species. Study results have shown that although the effects of site preparation, weed control and edaphic conditions affect black walnut growth, site suitability is key to good growth. Generally black walnut is found on deep, moist, well-drained areas having good soil structure and near-neutral pH 6.5-7.2 (Spurway 1941; Wilde 1934). Attempts to establish black walnut trees on shallow soils or excessively wet soils usually fail. Very poorly drained natural soils are considered unsuitable (Losche 1971).

Soil reaction and nutrient levels were related to walnut growth in 15-year-old walnut plantations in southeastern Iowa (Thompson and McComb 1962). Prediction equations using important soil and topographic variables were generated for northeast Kansas by Geyer et al. (1980). Recently, Wallace and Young (2008) developed a computer model that rates soils in Missouri for suitability to grow black walnut when physical properties from existing databases are loaded into the model.

Equations that describe the relationship between site factors and tree height for trees of specific ages yield fairly accurate predictions of site index. Therefore, agricultural croplands can be rated for their suitability to grow walnut as part of an agroforestry practice by comparing cropland soil properties to soil properties on forested black walnut sites that are highly correlated to height growth at site index 50 .

Our study attempts to relate tree growth differences as indicated by site index at 50 years to physical and chemical site factors.

\section{Materials and methods}

The study area is located within the Central Lowlands physiographic province and is mainly in the Osage Questas: a lesser portion is in the Cherokee Lowlands, and a small portion in the Chautaqua Hills and Ozark Plateau. Elevations range from 243 to $366 \mathrm{~m}$. The surface soils are mostly silt loam to clay loam texture, often with limestone and shale outcropping rocks on the slopes. Most are of Mollisol origin. The climate is typical continental with most of the precipitation falling in the growing season. The study range covered over $217 \mathrm{~km}$ north to south and $185 \mathrm{~km}$ east to west with moisture patterns of $114 \mathrm{~cm}$ in the SE and to $71 \mathrm{~cm}$ annual precipitation in the NE portions of the study area.

\section{Stand measurements}

Field plots. We measured trees in over 210 plots with over 10 black walnut trees. The plots were located on the unglaciated area of southeastern Kansas on all topographic positions (upland, bottomland, lower slopes, and intermittent streams) and generally well distributed in all four direction quadrants.

Trees selected for analysis were in the dominant and/or codominant crown classes and had no visible signs of stagnation or suppression. We measured two to four trees in each plot and took wood increment cores at about $15.2 \mathrm{~cm}$ above the ground to determine tree age.

Total height of each tree was measured with a Blume-Leiss altimeter from about $15.2 \mathrm{~cm}$ above the ground. Using Kellogg's site index curves to rate the productivity of the site for walnut plantations (Kellogg 1939) and plot averages of height and age, we evaluated site quality as the average height of dominant and codominant trees in a stand at age 50 years (site index). Taller trees at a given age indicate a site of higher productivity.

Site and soil chemical and physical variables

We classified each soil profile according to the following parameters:

(1) Each soil profile was classified by soil origin (soil parent material), either alluvial or residual, assigned values of +1 and -1 , respectively.

(2) Landform was classified as bottomland, intermittent stream, lower third slope or upland, and assigned values of $1,2,3$, or 4 .

(3-5) Azimuth (aspect) with an altimeter were determined with a compass pointed down slope through plot center. Assuming the 
northeast aspect as the most favorable for tree growth and southwest aspect as the least favorable, we tested two transformations of aspect. First, the cosine (azimuth $-45^{\circ}+1$ as described by Beers et al. (1967) and second, the corrected azimuth from the southwest as described by Munn (1974) along with true azimuth to see if they would correlate significantly with walnut growth.

(6-10) Slope \% was expressed as slope percentage, $<10 \%$, exceeding $10 \%$, and exceeding $15 \%$ and assigned whole number values of +1 or -1 were assigned for testing.

(11) Distance downhill to nearest water course.

(12) Effective soil depth minus rock contents (Steinbrenner 1965).

(13) Depth to a restrictive layer (DRL) defined as textural $\mathrm{B}_{2}$ horizon, a massive rock layer, and pure sand at least a $2.5 \mathrm{~cm}$ thick, or gravel layer of at least $75 \%$ rock, a summer water table, mottling $<152 \mathrm{~cm}$, or no mottling within $152 \mathrm{~cm}$, whichever occurred at the least depth.

(14) Total soil depth.

(15) Water holding capacity of total soil (WHCTSD). Sum of available water-holding capacity calculated by textural horizon.

(16) Water-holding capacity to the restrictive layer was determined by sum of available water-holding capacity calculated by textural horizon.

$(17,18)$ Soil textures were determined by the Bouyoucous method (1951), except sodium hexametaphosphate was used instead of Calgon as a dispersing agent.

(19-24) \% sand, clay, and silt + clay for both the upper and lower horizons. Chemical tests were run for both the surface and subsurface horizons. Variables were recorded for upper and lower horizons.

(25-31) The determination of lime (ECC/ac), $\mathrm{pH}$, Bray $1 \mathrm{P}$ (ppm), Ca (ppm), K (ppm), Na $(\mathrm{ppm})$, and organic matter for surface and subsurface horizons were done by the Kansas State University Soil Testing Laboratory using standard agricultural testing procedures.

Simple correlations of 32 variables of soil and topographic characteristics were calculated with the independent variable, site index (SI), to find the best practical variables based upon high simple correlation values. Significance was at the $5 \%$ level. A multiple regression equation was generated to find a more exact determination of combined values affecting site index using the stepwise backward elimination procedure (Barr et al. 1976) with all 32 variables. The combination tested at the $15 \%$ level of significance.

\section{Results and discussion}

Stand characteristics

Stand density based on basal area (BA) was 6.9-32.1 sq $\mathrm{m} / \mathrm{ha}$ with a mean of $17 \mathrm{sq} \mathrm{m} / \mathrm{ha}$, diameter at breast height ranged from 10.1 to $55.9 \mathrm{~cm}$ with a mean of $31.5 \mathrm{~cm}$, age ranged from 20 to 74 years with a mean of 47 , total height ranged from 6.1 to $25.6 \mathrm{~m}$ with a mean of $16.6 \mathrm{~m}$.

Understory vegetation

No significant differences occurred in height growth between the types of understory vegetation at the time of measurement (Prob. 0.9572). Thus, neither a grassy or woody understory had any effect on site index at this later age with no way of determining this over the years. We tested whether or not vegetation in the latter years had an unlikely effect and it did not. Size and age of trees likely nullified vegetative competitive influence. In other studies with younger trees, the effects of understory vegetation have reportedly reduced height growth of walnut (VanSambeek and McBride 1991; Ares and Brauer 2004). Tall fescue was shown to be especially troublesome.

Soil chemical characteristics

A few soil nutrient concentrations were important to the site index multiple regression equation; $\mathrm{Na}$, and Bray P. Optimum walnut growth has been suggested to occur when soil $\mathrm{pH}$ values range from 6.0 to 8.0 (Spurway 1941). Black walnut is common on many limestone soils within its native range (Williams 1990).

Soil physical characteristics

The majority of the stands in our study were noted to be on soils classified as Mollisols with some Alfisoils 
(75 and $25 \%$, respectively) and not evaluated with site index. All had horizons that reduced effective soil depth, or a restrictive layer that limited tree growth. Generally, factors relating to moisture availability are considered to be of utmost importance to tree growth.

Analyses of the data showed the highest simple correlation of site index was with DRL $(r=+0.85)$. Other highly correlated factors to site index were rooting depth, expressions of water-holding capacity, and soil parent material. Three of the four factors (soil depth, rooting depths, and expressions of waterholding capacity) are very closely related or influenced by each other. Deep soils can hold more water and have more space for root development. Soil moisture is likely the underlying factor associated with the high correlation of soil depth and site index. Various soils have bulk density levels at which compaction starts to limit root growth. When root growth is limited, the uptake of water and nutrients by vegetation is reduced.

Ares and Brauer (2004) concluded that a reduction of the effective soil depth-either by fragipan or bedrock layer-and stoniness likely limited tree growth on some of the 54 black walnut stands in their survey which compared growth and nut production of black walnut in relation to site, tree type, and stand conditions in south central United States. Unlike some tree species that develop both large and small roots descending diagonally from their trunks, black walnut develops a strong main root descending vertically from the underside of its trunk, thus requiring an unrestricted soil depth of one meter or more for adequate root development (Büsgen et al. 1929). Although black walnut's propensity to acquire nutrients and moisture influences roots to descend to greater depths, physical soil properties and aeration can restrict their ability to grow deeper.

Even though black walnut is deep-rooted, almost $80 \%$ of its root system occupies the upper $61 \mathrm{~cm}$ of soil (Pham et al. 1977). Water needs for black walnut are greatest during the growing season at a time when soil water content within the rooting zone decreases due to plant uptake and evapotranspiration. Carpenter and Hanover (1974) reported that black walnut seedling height growth slows after mid-June and ceases by late July, suggesting that seasonal height growth is completed early for the species. These authors also suggested that black walnut is typical of those deciduous species with preformed seasonal shoot growth.
Black walnut is believed to function as a droughtavoidance species as opposed to drought-tolerant species (Lucier and Hinckley 1982). As a droughtavoidance species, black walnut is able to maintain plant water content near optimum levels during periods of low soil moisture availability and high atmospheric evaporative demands by initiating stomatal closure, thus restricting photosynthesis and, depending on the duration of unfavorable conditions, shedding leaves. An earlier investigation of black walnut site quality in relation to soil characteristics in northeastern Kansas indicated that site index increased as effective soil depth increased (Geyer et al. 1980).

Surprisingly, neither aspect $(r=-0.006, p=0.971)$ nor silt + clay (sur. $r=0.122, p=0.452$, sub. $r=$ $0.098, p=0.566$ ) was important to black walnut site quality in northeastern Kansas (Geyer et al. 1980). The lack of correlation between aspect and site and between sand content and site suggest that although the basic soil and site requirements for the species do not change over the landscape, factors contributing to site requirements do change in importance among sites. Throughout its range, walnut generally reaches its greatest size and value along streams and on the lower portion of north- or east-facing slopes. This is particularly true near the western limits of its natural range. In northeastern Kansas, site index on alluvial soils was $2.4 \mathrm{~m}$ greater than on residual soils and $2.7 \mathrm{~m}$ greater on northeast than on southwest aspects (Geyer et al. 1980).

Soil texture was a major determining factor in the growth of planted walnuts in Kentucky (Kalisz et al. 1989). The growth rates of young black walnut plantations were significantly greater on suitable compared to questionable soils. In the Kentucky study, approximately $75 \%$ of the soils judged to be questionable for walnut management were limited by the presence of clay subsoil, $10 \%$ by shallowness to bedrock, $10 \%$ by imperfect drainage, and $5 \%$ by the presence of a fragipan. Stone and Kalisz (1990), in their review of vertical and radial extension of tree roots, reported that 15 -year-old black walnut growing on silty clay loam soil had a vertical root extension of $3.3 \mathrm{~m}$ and a radial root extension of $4.5 \mathrm{~m}$, whereas 25 -year-old black walnut growing on clay soil had a vertical root extension of $1.6 \mathrm{~m}$ and a radial root extension of $16.5 \mathrm{~m}$. Apparently, the wider radial expansion of walnut roots on clay soil compensated for the difficulty of vertical root penetration in the clay 
soil. Ripping compacted soils has been suggested as a way to improve water penetration and internal soil structure, thereby increasing the effective rooting depth for some tree species (Dennington 1989). But the growth of 10-year-old planted black walnut did not increase after ripping the clay loam subsoil and silt loam fragipan during site preparation (Van Sambeek and McBride 1991).

The relationship to thickness of the A horizon gave an " $r$ " value of 0.503 and $p=<0.0015$ (Table 1). However, taking soil texture into account in this layer is important because texture affects soil water storage and availability. Another study (Geyer et al. 1980) found that correlation coefficients for soil texture in the A horizon decreased with an increase in clay and increased when the silt content of the clay increased.

Functions to predict site quality

Many of the site factors were related to each other; we selected those most apparent and understandable for determining our multiple regression equations to predict height. We generated an equation that is practical for making field determinations of site index. We explained $73 \%$ of the variation in height with just two physical variables, soil origin (alluvial) and depth to restrictive layer.

The resulting equation was site index

$=13.7+0.01(\mathrm{SO})+0.72(\mathrm{DRL})$

When soil chemical factors were included our prediction did not improve much, at being $79 \%$. Site index equation $=25.9+0.73(\mathrm{DRL})+0.02(\mathrm{US})+$ $0.01(\mathrm{LSC})+0.01$ (Bray) +0.0 .01 (Una) +0.01 (SCB) (Table 2).

\section{Summary and conclusion}

The practice of agroforestry has a long-term and continual effect on maintaining and improving soil fertility (Xu 2000). Evaluating the soils before
Table 1 Simple correlations of physical factors related with site index for southeast Kansas

\begin{tabular}{llcll}
\hline Variable & Symbol & Mean $(\mathrm{cm})$ & Range $(\mathrm{cm})$ & $\begin{array}{l}\text { Simple } \\
\text { correlation (r) }\end{array}$ \\
\hline Depth to restrictive layer & DRL & 81.0 & $7.6-152.4$ & +0.85 \\
Est. soil depth to DRL & ESDRL & 79.8 & $2.1-23.6$ & +0.82 \\
Water holding capacity to DRL & WHCRL & 15.7 & $7.6-152.4$ & +0.82 \\
Soil origin (upland/bottomland) & SO & - & - & +0.67 \\
Landform (upland/slope/bottomland) & LF & - & - & -0.67 \\
Thickness "A" horizon & A & 50.8 & $5.1-152.4$ & +0.66 \\
Total soil depth & TSD & 112.0 & $15.2-152.4$ & +0.66 \\
Estimated soil depth & ESD & 104.1 & $12.7-152.4$ & +0.82 \\
Water holding capacity total horizon & WHCP & 23.1 & $2.54-152.5$ & +0.63 \\
\hline
\end{tabular}

Table 2 Partial R-square value in stepwise regression analysis southeastern, Kansas

\begin{tabular}{llll}
\hline Variable & $\begin{array}{l}\text { Total } \\
R \text {-square }\end{array}$ & $\begin{array}{l}\text { Physical variables } \\
\% \text { (total) }\end{array}$ & $\begin{array}{c}\text { Chemical variables } \\
\% \text { (total) }\end{array}$ \\
\hline Physical & 0.7303 & DRL $0.7205(98.7 \%)^{\mathrm{a}}$ & - \\
& & Soil $0.0098(1.3 \%)$ & Upper Bray $0.0101(1.2 \%)$ \\
Physical chemical & 0.7926 & DRL $0.7263(91.9 \%)$ & Upper Na .0074 $(0.9 \%)$ \\
& & US $0.0204(2.5 \%)$ & \\
& LSC $0.0124(1.5 \%)$ & \\
& LS $0.0079(1.0 \%)$ & \\
& SCB $0.0081(1.0 \%)$ &
\end{tabular}

${ }^{a}$ Contribution to total R-square; variation in site index

$D R L$ depth to restrictive layer, $U S \%$ sand A horizon, $L S C$ \% clay B2 horizon, $L S \%$ sand B2 horizon, $S C B \%$ silt + clay B2 horizon, UBray A horizon, UNa sodium A horizon 
applying agroforestry could be beneficial on sites where no trees near index age are present or useful in predicting height growth of trees, especially when considering black walnut as the tree crop. Soil origin was an important predictor of height growth for black walnut stands in southeastern Kansas. The positive coefficient in the equation for this variable indicates that site index increased when soil was of alluvial origin. Many factors used in this study were related to each other, and we selected those most easily recognizable in developing our multiple regression equations. Avoiding sites with shallow soils and other properties that reduce water availability and concentrating management on good sites will save resources and increase the growth and value of the trees. Growing walnut on bottomland (riparian) sites is ideal for commercial log production. Less desirable, shallow soil sites are limited to windbreaks, silvopastoral/ cattle protection, and nut production.

Although data for this study were collected southeastern Kansas, these results should be helpful elsewhere in most of eastern Kansas, southeastern Nebraska, southwestern Oklahoma, and western Missouri.

\section{References}

Ares A, Brauer D (2004) Growth and nut production of black walnut in relation to site, tree type, and stand condition in south-central United States. Agrofor Syst 63:83-90

Barr AJ, Goodnight JH, Sall JP, Helwig JT (1976) A user's guide to SAS. SAS Institute, Inc, Raleigh, p 329p

Beers TW, Dress PE, Wensel LC (1967) Aspect transformation in site productivity research. J Forest 65:22-24

Bouvoucos GJ (1951) A recalibration of the hydrometer method for making mechanical analysis of soils. Agron J 43: 432-437

Brinkman KA (1957) Silvical characteristics of black walnut. U.S. Forest Service Central States Forest Experiment Station. Miscellaneous publication. No. 22

Büsgen M, Münch E, Thomsom T (1929) The structure and life of forest trees. Chapman and Hall, London, p 300p

Carpenter SB, Hanover JW (1974) Comparative growth and photosynthesis of black walnut and honey locust seedlings. For Sci 20:317-324

Dennington RW (1989) Ripping can improve tree planting success. U. S. Forest Service Management Bulletin R8-MB 31

Garrett HE, Rieetveld, Fisher RF (2000) North American agroforestry: an integrated science and practice. American Society of Agronomy, Inc, Madison, p 402

Geyer WA, Marquard RD, Barber JF (1980) Black walnut site quality in relation to soil and topographic characteristics in northeastern Kansas. J Soil Water Conserv 35:135-137
Grey GW, Naughton G (1971) Ecological observations on the abundance of black walnut in Kansas. J For 69(10):741-743

Kalisz PJ, Stringer JW, Wells DB (1989) Growth of young black walnut plantations in Kentucky. Northern $\mathrm{J}$ Appl For 6(1):17-20

Kellogg LF (1939) Site index curves for plantation black walnut in the central states region. Forest Service, note no. 35. USDA Central States Forest Experiment Station, Columbus, $\mathrm{OH}$

Losche CK, Clark WM, Voss EE, Ashley BS (1971) Guide to the selection of soil suitable for growing black walnut in Illinois. USDA Forest Service and USDA Soil Conservation Service, North Central Forest Experiment Station

Lucier AA, Hinckley TM (1982) Phenology, growth, and water relations of irrigated and non-irrigated black walnut. For Ecol Manage 4:127-142

Munn LC (1974) Predicting height growth of yellow-poplar from soils and topography on a Muskingum-Berks-Neotoma soils complex in southeastern Ohio. MS thesis. Ohio State University, Columbus, $\mathrm{OH}$

Pham CH, Yen CP, Cox GS, Garrett HE (1977) Slope position, soil water storage capacity, and black walnut root development. In: Balmer WE (ed) Soil moisture-site productivity management symposium. USDA Forest Service, Southern Forest Experiment Station, Myrtle Beach, SC, pp 326-335

Spurway GW (1941) Soil reaction $(\mathrm{pH})$ preferences for plants. Michigan Agricultural Experiment Station Bulletin 306. Michigan State University, East Lansing

Steinbrenner EC (1965) The influence of individual soil and physiographic factors on the site index of Douglas-fir in western Washington. In: Youngberg CT (ed) Forest soils relationships in North America. Oregon State University Press, Corvallis, pp 261-270

Stone EL, Kalisz PJ (1991) On the maximum extent of tree roots. For Ecol Manage 46:59-102

Thompson GW, McComb AL (1962) Growth of plantation black walnut in relation to $\mathrm{pH}$ and certain chemical factors of the soil. For Sci 8:322-333

USDA Forest Service (1980) Root characteristics of some important trees of eastern forests: a summary of the literature. USDA Forest Service, Eastern Region

Van Sambeek JW, McBride FD (1991) Grass control improves early growth of black walnut more than either deep ripping or irrigation. In: The 2nd conference on agroforestry in North America. Springfield, IL, August 1991. Association for Temperate Agroforestry, Columbia, MO, pp 42-57

Wallace DC, Young FJ (2008) Black walnut suitability index: a natural resources conservation service national soil information system based interpretive model. In: Michler $\mathrm{CH}$ (ed) Proceedings, 16th Central Hardwood Forest Conference, West Lafayette, Indiana, April 8-9, 2008. Gen Tech Rep NRS-P-24. USDA Forest Service, Northern Research Station, Newtown Square, pp 589-595

Wilde SA (1934) Soil relation to forestry, and its determination by simple tests. J Forest 32:415

Williams RD (1990) Juglans nigra L. black walnut. In: Burns RM, Honkala BH (technical coordinators) Silvics of North America. Agriculture Handbook 654. USDA, Washington, DC

$\mathrm{Xu} \mathrm{F}$ (2000) Study on temporal processes of sloping agroforestry system. J Soil Water Conserv 14:46-50 